\title{
BELAJAR BERSAMA PARA JAMAAH DI PERPUSTAKAAN MASJID
}

\author{
Efi Rosfiantika ${ }^{1}$, Pawit M Yusup ${ }^{2}$ \\ ${ }^{1,2}$ Program Studi Ilmu Perpustakaan Universitas Padjadjaran \\ 1efi.rosfiantika@unpad.ac.id, ${ }^{2}$ pawit.m.yusup@unpad.ac.id
}

ABSTRACT - The mosque is a place of worship for Muslims, both in nature mahdoh and ghoerumahdhoh. In the context of worship latter, very broad and diverses, one of which is a mosque used as a place of activities for the benefit of mankind. One of the activities is to build mosque to learn add to the general knowledge and religious through reading. Means and facilities for reading in mosque activities carried out by the Mosque Library. These activities are not directly become binding pilgrims to stay longer while reading in the library of the mosque. One example of such activities include: (1) discussion and shared learning and reading and its implications for the intellectual development of Muslims in general; (2) the provision of facilities books and other media that are useful; (3) The activities of assistance to pilgrims in learning and reading according to their specialization.

Keywords: Mosque library, readings, learning together

ABSTRAK - Masjid adalah tempat ibadah bagi Muslim, baik di alam mahdoh dan ghoerumahdhoh. Dalam konteks penyembahan kedua, dan diverses sangat luas, salah satu yang adalah sebuah masjid digunakan sebagai tempat kegiatan-kegiatan untuk kepentingan manusia. Salah satu kegiatan adalah untuk membangun masjid untuk mempelajari menambahkan ke pengetahuan umum dan melalui agama membaca. Berarti fasilitas dan untuk membaca masjid di kegiatan yang dilakukan oleh Perpustakaan Masjid. Kegiatan ini tidak langsung menjadi mengikat peziarah untuk tinggal lebih lama di saat membaca di perpustakaan masjid. Salah satu contoh dari kegiatan-kegiatan seperti ini mencakup: (1) diskusi dan belajar bersama dan membaca dan implikasi untuk perkembangan intelektual Muslim secara umum; (2) penyediaan fasilitas buku dan media lain yang berguna; (3) aktiviti-aktiviti bantuan kepada peziarah dalam pembelajaran dan membaca menurut spesialisasi mereka.

Kata kunci: Perpustakaan masjid, membaca, belajar bersama

\section{PENDAHULUAN}

Banyak orang tahu dan beranggapan bahwa masjid adalah tempat sholat umat Islam. Di manapun masjid itu berada, kesan seperti itu tetap melekat pada sebagian besar orang. Selain itu, orang juga mengetahui masjid dijadikan tempat sholat, baik munfarid (sendirian) maupun sholat berjamaah, tempat pengajian, dan hanya sekali- sekali dijadikan tempat musyawarah dalam rangka menyelesaikan persoalan umat dan jamaah masjid secara insidental. Lihat saja misalnya, sehabis sholat wajib, praktis masjid menjadi kosong karena para jamaah meninggalkannya untuk suatu keperluan. Baru kemudian masjid ada penghuninya ketika datang waktu sholat wajib berikutnya. Belum lagi persoalan sedikit atau banyaknya jamaah yang hadir di masjid pada setiap kali waktu sholat tiba.

Masjid seolah hanya dijadikan tempat sholat wajib yang rutin dilakukan oleh umat 
Islam, bahkan hanya sebagian kecil saja dari umat Islam yang datang ke masjid untuk melakukan ibadah sholat. Padahal, bentuk-bentuk ibadah dalam konsep Islam banyak sekali, terutama ibadah yang termasuk kategori ghoeru mahdhoh atau ibadah selain yang sudah ditetapkan tatacara dan aturannya dalam Qur'an dan Hadis. Contoh ibadah kategori ini antara lain adalah: bekerja dengan ikhlas, menuntut ilmu, mencari rizki, menolong orang lain, menyediakan fasilitas untuk belajar orang lain, dsb. Jika bentuk-bentuk pekerjaan tersebut dilakukan dengan ikhlas karena Allah, maka semua itu bernilai ibadah, dan tentu mendapatkan pahala.

Dalam konteks ibadah ghoeru mahdhoh seperti dikemukakan di atas, kegiatan membina umat dan jamaah dalam rangka untuk mengupayakan agar jamaah merasa terikat secara terus-menerus dengan masjid dengan segala kegiatannya, juga termasuk dalam praktik ibadah. Bentuk-bentuk pembinaan dimaksud banyak jenisnya, pembinaan jamaah agar selalu sholat wajib di masjid, pembinaan umat melalui berbagai kegiatan pengajian, kegiatan saritilawah, pelatihan berwirausaha bagi jamaah remaja masjid, kegiatan pelatihan berpidato, pelatihan menjadi pendakwah, pembinaan minat membaca, kegiatan berdiskusi mengenai masalah kehidupan sehari- hari, kegiatan membaca dan bedah buku yang disediakan oleh perpustakaan masjid, dsb. Banyak hal yang bisa dilakukan di dan mellui kendali masjid. Intinya, masjid bisa dijadikan pusat pendidikan, perjuangan, dakwah, dan kegiatan lain yang bernilai ibadah.

Data tentang masjid di Indonesia jumlanya sangat banyak. DMI (Dewan Masjid
Indonesia) Pusat mencatat lebih dari 700.000 masjid dan musholla tersebar di Indonesia. Jumlah itu terus bertambah seiring dengan jumlah penduduk yang beragama Islam dan juga karena perkembangan Islam sendiri. Sekretaris Ditjen Bimas Islam Kemenag Muhammadiyah Amin memaparkan bahwa peningkatan jumlah masjid dan mushala sejak awal pencatatan oleh Kemenag pada 2009 cukup baik. Data tahun 2009 menunjukkan jumlah masjid dan mushala berjumlah 409.402 buah; kemudian pada tahun 2010jumlahnya mengalami peningkatan, yakni menjadi 419.273 buah. Selanjutnya, angka tersebut naik cukup tinggi pada pada tahun berikutnya, yakni tahun 2011 yang jumlahnya mencapai 709.646 buah; naik lagi pada tahun 2012 menjadi 720.292 buah; dan pada tahun 2013, terdapat 731.096 bangunan masjid dan ushola. (Sumber: Republika Online, $6 \mathrm{Mei}$ 2015).

Data di atas dimaksudkan sebagai informasi bahwa masjid dan ushola sebagai tempat ibadah umat Islam, jumlahnya terus bertambah dan berkembang. Perkembangan ini tentu termasuk dalam kegiatan-kegiatan yang dilakukan di dan atas kendali masjid dan atau mushola. Sejumlah sarana dan fasilitas untuk mendukung kegiatan ibadah di masjid pun tersedia di dalamnya. Sejumlah bahan bacaan berupa Al-Qur'an, buku-buku hadis, dan bukubuku keagamaan lainnya, juga tersedia di masjid dan atau mushola ini.

Di tingkat lokal sebagai contoh, hasil prasurvei yang dilakukan oleh tim peneliti pada awal tahun 2015 menggambarkan bahwa setiap masjid yang ada di Kecamatan Rancaekek 
Kabupaten Bandung, sudah memiliki sejumlah bahan bacaan, baik berupa Al-Qur'an, buku hadis, ataupun buku berkonten keagamaan lainnya. Jumlah bahan bacaan dimaksud bervariasi pada setiap masjid. Ada yang hanya terdiri atas beberapa Al-Qur'an yang jumlahnya kurang dari sepuluh eksemplar dan beberapa eksemplar buku hadis, sampai dengan koleksi bahan bacaan yang mencapai lebih dari sepuluh eksemplar. Jumah koleksi bahan bacaan yang jumlahnya puluhan dan bahkan ratusan inilah yang dalam tingkatan sederhana bisa dianggap sebagai Perpustakaan Masjid, meskipun belum sepenuhnya memenuhi kaidah sebagai perpustakaan yang memadai sesuai dengan standar perpustakaan umum.

Kondisi keberadaan koleksi bahan bacaan yang sudah ada di masjid-masjid ini, pada prinsipnya bisa dikatakan sebagai cikal bakal lahirnya Perpustakaan Masjid yang memenuhi standar perpustakaan yang benar. Fungsi dan manfaat dari bahan bacaan yang tersedia di masjid ini adalah untuk memenuhi kebutuhan jamaah masjid akan informasi dan pengetahuan. Para jamaah biasanya setelah memasuki masjid dan melakukan sholat sunat dan berdoa, sambil menunggu waktu sholat wajib berjamaah, sebagian ada yang terus berdoa dan sebagian lagi ada yang membaca Al-Qur'an dan bahan bacaan lainnya yang disediakan oleh masjid. Demikian pula setelah para jamaah selesai melakukan sholat wajib dan dilanjutkan sholat sunat dan berdoa, sambil menunggu waktu sholat wajib berikutnya, biasanya waktu antara setelah sholat Magrib dan sebelum sholat Isya, mereka membaca Al-Qur'an dan bahan bacaan keagamaan lainnya.
Dengan kondisi keberadaan koleksi Al'Qur'an dan buku bacaan lain yang jumlahnya tidak banyak saja, sudah dimafaatkan dengan cara dibaca oleh para jamaah. Dengan data dan asumsi seperti ini, maka jika jumlah bahan bacaan berupa Al-Qur'an dan buku-buku tentang ditambah dan dikelola dengan lebih baik, diharapkan akan lebih banyak lagi jamaah yang memanfaatkannya. Kondisi seperti ini akan terus dilakukan secara rutin oleh para jamaah, sehingga dalam jangka panjang, para jamaah akan merasa terikat dengan keberadaan masjid dengan segala kegiatan dan fasilitasnya. Dan, salah satu fasilitas dimaksud adalah adanya perpustakaan masjid yang bisa memenuhi kebutuhan akan informasi dan pengetahuan para jamaah.

Atas dasar uraian seperti dikemukakan di atas, tim peneliti ingin mengkaji lebih jauh tentang bagaimana keberadaan perpustakaan masjid dengan segala fungsinya bisa mengikat para jamaah melalui kegiatan membaca bahan bacaan yang disediakannya.

Dari paparan data tentang keberadaan masjid dan perpustakaan masjid sebagai bagian tak terpisahkan dari masjid dan kegiatankegiatannya, dapat dirumuskan masalah sebagai berikut: Bagaimana cara mengikat para jamaah masjid agar mereka merasa terikat dan senang menjadi bagian dari keberadaan masjid melalui kegiatan membaca yang difasilitasi oleh Perpustakaan Masjid?

Rumusan masalah di atas bisa dipecah ke dalam masalah-masalah yang lebih sempit praktis sebagai berikut: (1) Bagaimana cara melakukan diskusi dan pembelajaran bersama dengan jamaah masjid mengenai membaca dan implikasinya bagi 
perkembangan intelektual umat islam pada umumnya; (2) Bagaimana cara menyediakan sarana dan fasilitas berupa penyediaan koleksi buku dan media bacaan lain berkonten pengetahuan umum dan keagamaan, yang bisa dijadikan media pengikat jamaah masjid untuk tinggal berlama-lama di msjid dengan membaca; dan (3) Bagaimana cara mendampingi para jamaah untuk belajar membaca dan mengaplikasikan hasil bacaan sesuai dengan peminatan mereka.

\section{TINJAUAN PUSTAKA}

Rujukan pertama tentang penyelenggaraan fasilitas bahan bacaan di masjid, yang nantinya akan menjadi perpustakaan masjid, adalah wahyu Allah yang pertama kali diturunkan kepada Nabi Muhammad SAW, yakni Surat Al'Alaq ayat 1-5, sebelum ayat-ayat lain diturunkan. Ini artinya kedudukan dan tugas membaca itu teramat penting dalam kehidupan umat manusia. Ayat selengkapnya adalah: (1) Bacalah dengan (menyebut) nama Tuhanmu Yang menciptakan; (2) Dia telah menciptakan manusia dari segumpal darah; (3) Bacalah, dan Tuhanmulah Yang Maha Pemurah; (4) Yang mengajar (manusia) dengan perantaran kalam; (5) Dia mengajar kepada manusia apa yang tidak diketahuinya. Intinya, kegiatan membaca adalah wajib bagi seluruh umat manusia, dan perpustakaan masjid berusaha untuk menyediakan bahan bacaan dimaksud.

Rujukan berikutnya adalah Undangundang RI No. 43 tahun 2007 tentang Perpustakaan. Di undang-undang ini, terutama pasal 22 ayat 4, dicantumkan bahwa masyarakat dapat menyelenggarakan perpustakaan umum untuk memfasilitasi terwujudanya masyarakat pembelajar sepanjang hayat. Konteks ini mengandung arti bahwa perpustakaan umum, termasuk perpustakaan masjid, bisa diselenggarakan oleh masyarakat. Melalui perpustakaan masjid, para jamaah di masjid yang bersangkutan, atau masyarakat sekitar masjid, bisa memanfaatkan perpustakaan. Dengan adanya fasilitas dan sarana belajar berupa perpustakaan masjid yang diselenggarakan oleh masyarakat pengurus masjid, maka sedikit banyak hal ini bisa menjadi ajang silaturahim antar jamaah masjid, menjadi tempat berkumpulnya anggota jamaah masjid, dan menjadi tempat belajar bagi anggota jamaah masjid. Pada pasal 48 undang-undang ini juga mencatat hal yang berkait dengan kegemaran membaca yang diinisiasi dan difasilitasi oleh perpustakaan. Lengkapnya, Undang-undang Republik Indonesia Nomor 43 Tahun 2007 tentang Perpustakaan, pasal 48 mencatat bahwa:

(1) Pembudayaan kegemaran membaca dilakukan melalui keluarga, satuan pendidikan, dan masyarakat.

(2) Pembudayaan kegemaran membaca pada keluarga sebagaimana dimaksud pada ayat (1) difasilitasi oleh Pemerintah dan pemerintah daerah melalui buku murah dan berkualitas.

(3) Pembudayaan kegemaran membaca pada satuan pendidikan sebagaimana dimaksud pada ayat dilakukan dengan mengembangkan dan memanfaatkan perpustakaan sebagai proses pembelajaran.

(4) Pembudayaan kegemaran membaca 
pada masyarakat sebagaimana dimaksud pada ayat(1) dilakukan melalui penyediaan sarana perpustakaan di tempat-tempat umum yang mudah dijangkau, murah, dan bermutu. Sejalan dengan amanat seperti tersebut di

atas, jamaah masjid bisa melakukan proses pembelajaran masyarakat melalui penyelenggaraan perpustakaan masjid. Dalam prakteknya, jamaah masjid tidak mengenal libur untuk datang ke masjid. Artinya, setiap hari sepanjang tahun, mereka datang ke masjid untuk melaksanakan sholat.

Kepustakaan berikutnya adalah seperti ditulis oleh Yusup, Pawit M. (2009) yang mengungkapkan hasil penelitian dari Kalba pada tahun 1977, bahwa hasil penelitian di Amerika Serikat menunjukkan bahwa "dalam menghadapi sebagian besar permasalahannya, hanya tiga persen saja dari seluruh responden yang mencari informasi melalui perpustakaan". Data ini memang tidak mengenakkan bagi dunia perpustakaan pada umumnya. Di Indonesia, belum ada data yang akurat tentang itu. Namun hal seperti itu mungkin tidak berlaku untuk perpustakaan masjid, karena ada perbedaan prinsip dan cara pandang pengguna perpustakaan pada umumnya dengan jamaah masjid sebagai pengguna perpustakaan. Jamaah masjid secara rutin dan setia datang ke masjid untuk melakukan sholat lima waktu, praktis tidak pernah ada libur.

Dengan melihat kondisi seperti ini maka penyediaan fasilitas untuk membaca berbagai buku dan bahan bacaan lain yang bisa menambah pengetahuan dan ilmu, sangat sesuai dengan upaya pembinaan umat. Dengan disediakannya fasilitas bahan bacaan oleh perpustakaan masjid, dalam jangka panjang, jamaah atau dalam skala yang lebih luas adalah umat, akan terbiasa dan merasa terikat dengan masjid.

Pustaka berikutnya adalah Peranan Perpustakaan Masjid dalam Pembinaan Umat (Waluyo, Subagio S. (2014). Di sini Waluyo menjelaskan tentang fungsi-fungsi perpustakaan masjid secara lebih operasional dan praktis. Fungsi masjid tidak hanya dijadikan tempat sholat saja melainkan sebagai kegiatan yang beranekaragam, dan semuanya bernilai ibadah. Ketika zaman Rasululloh dan Khulafaur Rasyidin), masjid ternyata mempunyai fungsi, bukan hanya untuk tempat sholat atau melaksanakan kegiatan-kegiatan yang temporer atau seremonial, melainkan banyak kegiatan di dalamnya. Contohnya sebagai berikut: sebagai pusat kegiatan keagamaan (keislaman) dan ibadah khusus; sebagai tempat bertemunya umat Islam; sebagai pusat dakwah dan pendidikan; sebagai tempat kegiatan kemasyarakatan; sebagai tempat mencari ketenangan; dan tempat istirahat para musafir. Dari keenam fungsi di atas, agaknya yang relevan dengan fungsi perpustakaan masjid ialah pusat dakwah, pendidikan, dan tempat kegiatan kemasyarakatan. Sebagai tempat pendidikan umat, perpustakaan masjid sangat relevan jika dikelola dengan baik sesuai dengan prinsip-prinsip pengelolaan perpustakaan.

Lebih jauh lagi, perpustakaan masjid bisa berfungsi sebagai pengikat jamaah masjid untuk selalu datang dan memanfaatkan segala fasilits yang disediakannya. Jika dirinci labih jauh, perpustakaan masjid bisa berfungsi sebagai 
berikut: (1) tempat belajar umat dan jamaah masjid serta masyarakat sekitarnya; (2) tempat mengkaji dan diskusi mengenai masalah-masalah sosial dan keagamaan; (3) tempat belajar melalui membaca dengan lebih tenang; (4) sebagai tempat untuk memotivasi umat dan jamaah serta penduduk sekitar masjid untuk membaca dan mencari informasi pengetahuan dan ilmu secara teratur; (5) tempat pembinaan minat baca jamaah anak, remaja, dan orang tua secara rutin; (6) tempat didokumentasikan informasi dan sumber- sumber informasi keagamaan sehingga pemanfaatannya bisa berumur panjang himgga generasi mendatang; (7) tempat atau ajang silaturahim umat dan jamaah masjid secara rutin. Ke-7 fungsi di atas jika dilakukan dan dikelola dengan benar oleh para pengurus perpustakaan masjid, akan dapat mengikat para jamaah untuk selalu merasa senang dan ikhlas dalam menjalani kegiatan beribadah di masjid dan masyarakat sosialnya.

\section{METODE PENELITIAN}

Action research digunakan sebagai metode untuk pelaksanaan kegiatan penelitian ini, sebab jenis metode ini cocok digunakan untuk menawarkan pendekatan sistematis terhadap suatu penemuan tertentu (Riding, Phil, Fowell, Sue and Levy, Phil:1995). Sifat dari action research ini bisa dilihat dari aspek dasar teoretis juga atas dasar pelaksanaan praktis, yang dua-duanya berorientasi pada produk. Jelasnya tidak memisahkan antara teori dan praktis dalam membangun paradigma penelitian ini. Aplikasi metode pada penelitian ini adalah adanya produk model yang dibangun atas dasar pemanfaatan fasilitas membaca yang dilakukan para jamaah masjid. Dengan adanya kegiatan membaca yang dilakukan di lingkungan masjid, maka diperlukan tersedianya bahan bacaan yang memadai. Bahan bacaan dimaksud lalu diperlukan pengelolaan yang memadai pula. Model pengelolaan fasilitas bahan bacaan inilah yang merupakan cikal bakal lahirnya perpustakaan masjid.

Sementara itu, teknik PRA (Participatory Rural Appraisal) secara teknis akan digunakan dalam pelaksanaan kegiatan penelitian tindakan ini. Konsep metode PRA pada dasarnya adalah kerangka konseptual, prinsip-prinsip, nilai ideologis, visi yang ingin dicapai, serta metode yang dapat digunakan untuk mengaplikasikan pemikiran tentang partisipasi dan pemberdayaan masyarakat. Sebagai metodologi, PRA merupakan kerangka kerja yang memiliki latar belakang teoretis yang menggunakan satu paradigma tertentu. Dalam tataran pelaksanaan, metode PRA merupakan alat-alat untuk mengembangkan proses-proses partisipasi masyarakat dalam pembangunan. (Sumber: Rianingsih Djohani,

2003). Konteks partisipasi dalam hal ini adalah keterlibatan para jamaah masjid dalam kegiatan membaca dan menggunakan fasilitas bahan bacaan lainnya yang disediakan oleh perpustakaan masjid.

Adapun langkah-langkah PRA yang dilakukan dalam kegiatan ini adalah sebagai berikut:

1. Melakukan pembelajaran bersama para jamaah mengenai pengetahuan dan ilmu yang bisa dibaca melalui buku dan media lain yang disediakan oleh perpustakaan masjid; 
2. Melakukan penyadaran terhadap sejumlah jamaah masjid mengenai potensi yang dimiliki masjid dan jamaahnya terkait penyediaan fasilitas bahan bacaan berkonten keagamaan;

3. Melakukan pengumpulan informasi dan sumber-sumber informasi yang dibutuhkan para jamaah masjid yang bersumber pada media cetak berupa buku dan bahan bacaan lain;

4. Melakukan pengembangan model visual mengenai teknik membaca dan mengelola bahan bacaan yang disediakan oleh perpustakaan masjid;

5. Melakukan langkah-langkah penyediaan sarana dan fasilitas berupa koleksi buku dan media bacaan lain berkonten pengetahuan umum dan keagamaan, yang bisa dijadikan media pengikat jamaah masjid untuk tinggal berlama-lama di msjid dengan membaca;

6. Melakukan pengembangan model-model pemanfaatan perpustakaan masjid dalam rangka pengikatan umat terhadap masjid sebagai rumah bersama untuk ibadah;

7. Melakukan pendampingan kepada para jamaah untuk belajar membaca dan mengaplikasikan hasil bacaan sesuai dengan peminatan mereka;

8. Melakukan pemantauan secara terusmenerus atas perkembangan model membaca untuk mengikat para jamaah masjid menjadi bagian dari sistem pemanfaatan perpustakaan yang terintegrasi

\section{HASIL DAN PEMBAHASAN}

Indikator capaian kegiatan yang nyata dalam penelitian tindakan ini adalah terselenggarakannya Perpustakaan Masjid yang masih terus berproses sejalan dengan tersedianya fasilitas dan biaya. Tabel berikut menggambarkan perbedaan antara sebelum dan sesudah dirintisnya Perpustakaan Masjid di Kompleks Permata Hijau Desa Jelegong Kecamatan Rancaekek Kabupaten Bandung.

Tabel: Capaian Kegiatan Penelitian

\begin{tabular}{|c|c|c|c|}
\hline No & Indikator & $\begin{array}{l}\text { Base Line } \\
\text { (sebelum } \\
\text { kegiatan) }\end{array}$ & $\begin{array}{l}\text { Pencapaian } \\
\text { setelah kegiatan }\end{array}$ \\
\hline 1 & $\begin{array}{l}\text { Melakukan } \\
\text { pembelajaran } \\
\text { bersama para } \\
\text { jamaah } \\
\text { mengenai } \\
\text { pengetahuan } \\
\text { dan ilmu yang } \\
\text { bisa dibaca } \\
\text { melalui buku } \\
\text { dan media } \\
\text { lain yang } \\
\text { disediakan } \\
\text { oleh } \\
\text { perpustakaan } \\
\text { masjid }\end{array}$ & $\begin{array}{l}\text { Sebagian } \\
\text { besar } \\
\text { jamaah } \\
\text { belum } \\
\text { mengenal } \\
\text { Perpustaka } \\
\text { an Masjid } \\
\text { sebagai } \\
\text { tempat } \\
\text { untuk } \\
\text { belajar } \\
\text { bersama }\end{array}$ & $\begin{array}{l}\text { Sebagian besar } \\
\text { jamaah sudah } \\
\text { mengenal } \\
\text { Perpustakaan } \\
\text { Masjid } \\
\text { sebagai tempat } \\
\text { untuk belajar } \\
\text { bersama }\end{array}$ \\
\hline
\end{tabular}




\begin{tabular}{|c|c|c|c|}
\hline 2 & $\begin{array}{l}\text { Melakukan } \\
\text { penyadaran } \\
\text { terhadap } \\
\text { sejumlah } \\
\text { jamaah masjid } \\
\text { mengenai } \\
\text { potensi yang } \\
\text { dimiliki } \\
\text { masjid dan } \\
\text { jamaahnya } \\
\text { terkait } \\
\text { penyediaan } \\
\text { fasilitas } \\
\text { bahan } \\
\text { bacaan } \\
\text { berkonten } \\
\text { keagamaan }\end{array}$ & $\begin{array}{l}\text { Fasilitas } \\
\text { bahan } \\
\text { bacaan di } \\
\text { masjid } \\
\text { masih } \\
\text { bersifat } \\
\text { terbatas } \\
\text { mengenai } \\
\text { kitab suci } \\
\text { Al-Qur'an } \\
\text { dan kitab- } \\
\text { kitab } \\
\text { hadis, } \\
\text { jumahnya } \\
\text { tidak } \\
\text { banyak } \\
\text { dan tidak } \\
\text { dianggap } \\
\text { sebagai } \\
\text { perpustak } \\
\text { aan } \\
\text { masjid }\end{array}$ & $\begin{array}{l}\text { Fasilitas bahan } \\
\text { bacaan di } \\
\text { masjid meskipun } \\
\text { masih bersifat } \\
\text { terbatas } \\
\text { mengenai kitab } \\
\text { suci Al-Qur'an } \\
\text { dan kitab-kitab } \\
\text { hadis, dan } \\
\text { jumahnya juga } \\
\text { masih tidak } \\
\text { banyak, namun } \\
\text { sudah dilengkapi } \\
\text { dengan sejumlah } \\
\text { koleksi bahan } \\
\text { bacaan yang } \\
\text { lebih bervariasi. }\end{array}$ \\
\hline 3 & $\begin{array}{l}\text { Melakukan } \\
\text { pengumpula } \\
\text { n informasi } \\
\text { dan sumber- } \\
\text { sumber } \\
\text { informasi } \\
\text { yang } \\
\text { dibutuhkan } \\
\text { para jamaah } \\
\text { masjid } \\
\text { yang } \\
\text { bersumber } \\
\text { pada media } \\
\text { cetak } \\
\text { berupa } \\
\text { buku dan } \\
\text { bahan } \\
\text { bacaan lain }\end{array}$ & $\begin{array}{l}\text { Selama ini } \\
\text { belum ada } \\
\text { upaya dari } \\
\text { para } \\
\text { pengurus } \\
\text { masjid } \\
\text { untuk } \\
\text { menghim } \\
\text { pun } \\
\text { bahan } \\
\text { bacaan } \\
\text { untuk } \\
\text { dijadikan } \\
\text { Perpustak } \\
\text { aan yang } \\
\text { lebih } \\
\text { representa } \\
\text { tif }\end{array}$ & $\begin{array}{l}\text { Sekarang } \\
\text { sudah ada } \\
\text { rintisan dan } \\
\text { upaya dari } \\
\text { para pengurus } \\
\text { masjid untuk } \\
\text { menghimpun } \\
\text { bahan bacaan } \\
\text { untuk dijadikan } \\
\text { Perpusta } \\
\text { kaan } \\
\text { yang } \\
\text { lebih } \\
\text { represent } \\
\text { atif }\end{array}$ \\
\hline
\end{tabular}

\begin{tabular}{|c|c|c|c|}
\hline 4 & $\begin{array}{l}\text { Melakukan } \\
\text { pengemban } \\
\text { gan model } \\
\text { visual } \\
\text { mengenai } \\
\text { teknik } \\
\text { membaca } \\
\text { dan } \\
\text { mengelola } \\
\text { bahan } \\
\text { bacaan yang } \\
\text { disediakan } \\
\text { oleh } \\
\text { perpustakaa } \\
\text { n masjid }\end{array}$ & $\begin{array}{l}\text { Belum } \\
\text { ada upaya } \\
\text { dan } \\
\text { kegiatan } \\
\text { yang } \\
\text { secara } \\
\text { khusus } \\
\text { dilakukan } \\
\text { oleh } \\
\text { masjid } \\
\text { dalam hal } \\
\text { mengimpl } \\
\text { ementasik } \\
\text { an bahan } \\
\text { bacaan } \\
\text { yang } \\
\text { berkonten } \\
\text { TTG- } \\
\text { Teknologi } \\
\text { Tepat } \\
\text { Guna }\end{array}$ & $\begin{array}{l}\text { Sudah ada } \\
\text { rintisan upaya } \\
\text { dan kegiatan } \\
\text { yang secara } \\
\text { khusus } \\
\text { dilakukan } \\
\text { oleh masjid } \\
\text { dalam hal } \\
\text { mengimpleme } \\
\text { ntasikan } \\
\text { bahan bacaan } \\
\text { yang } \\
\text { berkonten } \\
\text { TTG- } \\
\text { Teknologi } \\
\text { Tepat Guna, } \\
\text { melalui } \\
\text { kegiatan } \\
\text { membaca di } \\
\text { Perpustakaan } \\
\text { Masjid }\end{array}$ \\
\hline 5 & $\begin{array}{l}\text { Melakukan } \\
\text { langkah- } \\
\text { langkah } \\
\text { penyediaan } \\
\text { sarana dan } \\
\text { fasilitas } \\
\text { berupa } \\
\text { koleksi buku } \\
\text { dan media } \\
\text { bacaan lain } \\
\text { berkonten } \\
\text { pengetahuan } \\
\text { umum dan } \\
\text { keagamaan } \\
\text {, yang bisa } \\
\text { dijadikan } \\
\text { media }\end{array}$ & $\begin{array}{l}\text { Selama ini } \\
\text { belum ada } \\
\text { sarana dan } \\
\text { fasilitas } \\
\text { apapun } \\
\text { terkait } \\
\text { dengan } \\
\text { bahan } \\
\text { bacaan } \\
\text { yang } \\
\text { disediakan } \\
\text { di } \\
\text { lingkunga } \\
\text { n masjid, } \\
\text { kecuali } \\
\text { beberapa } \\
\text { kita suci } \\
\text { Al- } \\
\text { Qur'an } \\
\text { dan } \\
\text { buku } \\
\text { hadis. }\end{array}$ & $\begin{array}{l}\text { Sekarang sudah } \\
\text { ada lembari } \\
\text { atau rak buku } \\
\text { sebagai } \\
\text { bagian dari } \\
\text { sarana dan } \\
\text { fasilitas untuk } \\
\text { membangun } \\
\text { perpustakaan } \\
\text { masjid. } \\
\text { Lemari buku } \\
\text { dengan } \\
\text { kapasitas } 500 \\
\text { eksemplar }\end{array}$ \\
\hline
\end{tabular}




\begin{tabular}{|c|c|c|c|}
\hline 6 & $\begin{array}{l}\text { Melakukan } \\
\text { pengemban } \\
\text { gan model- } \\
\text { model } \\
\text { pemanfaata } \\
\text { n } \\
\text { perpustakaa } \\
\text { n masjid } \\
\text { dalam } \\
\text { rangka } \\
\text { pengikatan } \\
\text { umat } \\
\text { terhadap } \\
\text { masjid } \\
\text { sebagai } \\
\text { rumah } \\
\text { bersama } \\
\text { untuk } \\
\text { ibadah }\end{array}$ & $\begin{array}{l}\text { Kegiatan } \\
\text { membaca } \\
\text { yang } \\
\text { selama ini } \\
\text { sudah } \\
\text { dilakukan } \\
\text { dalam } \\
\text { bentuk } \\
\text { pengajian } \\
\text { rutin } \\
\text { untuk } \\
\text { kelompok } \\
\text { umum, } \\
\text { kelompok } \\
\text { bapa, } \\
\text { kelompok } \\
\text { itu, dan } \\
\text { kelompok } \\
\text { anak-anak }\end{array}$ & $\begin{array}{l}\text { Kegiatan } \\
\text { membaca yang } \\
\text { selama ini } \\
\text { sudah } \\
\text { dilakukan } \\
\text { dalam bentuk } \\
\text { pengajian rutin } \\
\text { untuk } \\
\text { kelompok } \\
\text { umum, } \\
\text { kelompok } \\
\text { bapa, } \\
\text { kelompok itu, } \\
\text { dan kelompok } \\
\text { anak-anak, } \\
\text { akan } \\
\text { dikembangk } \\
\text { an polanya } \\
\text { menjadi } \\
\text { implementas } \\
\text { ikan hasil } \\
\text { membacanya } \\
\text { pada } \\
\text { praktek } \\
\text { kehidupan } \\
\text { sehari-hari. } \\
\text { Misalnya ada } \\
\text { lomba } \\
\text { melaporkan isi } \\
\text { bacaan dan } \\
\text { diberi hadiah. }\end{array}$ \\
\hline
\end{tabular}

\begin{tabular}{|c|c|c|c|}
\hline 7 & $\begin{array}{l}\text { Melakukan } \\
\text { pendamping } \\
\text { an kepada } \\
\text { para jamaah } \\
\text { untuk belajar } \\
\text { membaca } \\
\text { dan } \\
\text { mengaplikas } \\
\text { ikan hasil } \\
\text { bacaan } \\
\text { sesuai } \\
\text { dengan } \\
\text { peminatan } \\
\text { mereka }\end{array}$ & $\begin{array}{l}\text { Selama ini } \\
\text { belum ada } \\
\text { pola } \\
\text { pendamp } \\
\text { ingan } \\
\text { membaca } \\
\text { yang } \\
\text { dilakuka } \\
\text { n oleh } \\
\text { para } \\
\text { pengurus } \\
\text { masjid, } \\
\text { kecuali } \\
\text { melalui } \\
\text { kegiatan } \\
\text { sekolah } \\
\text { TK dan } \\
\text { TKA } \\
\text { secara } \\
\text { formal }\end{array}$ & $\begin{array}{l}\text { Melalui } \\
\text { Perpustakaan } \\
\text { Masjid, } \\
\text { kegiatan- } \\
\text { kegiatan } \\
\text { pendampinga } \\
\text { n membaca } \\
\text { dan } \\
\text { implementasi } \\
\text { hasilnya bisa } \\
\text { dikembangka } \\
\text { n secara lebih } \\
\text { nyata, dengan } \\
\text { cara } \\
\text { meningkatka } \\
\text { n fungsi dan } \\
\text { peran } \\
\text { perpustakaan } \\
\text { masjid secara } \\
\text { terintegrasi } \\
\text { dengan } \\
\text { kegiatan } \\
\text { pendidikan } \\
\text { lainnya. }\end{array}$ \\
\hline 8 & $\begin{array}{l}\text { Melakukan } \\
\text { pemantauan } \\
\text { secara terus- } \\
\text { menerus atas } \\
\text { perkembang } \\
\text { an model } \\
\text { membaca } \\
\text { untuk } \\
\text { mengikat } \\
\text { para jamaah } \\
\text { masjid } \\
\text { menjadi } \\
\text { bagian dari } \\
\text { sistem } \\
\text { pemanfaatan } \\
\text { perpustakaan } \\
\text { yang } \\
\text { terintegrasi. }\end{array}$ & $\begin{array}{l}\text { Selama ini } \\
\text { belum ada } \\
\text { kegiatan } \\
\text { yang perlu } \\
\text { dipantau } \\
\text { terkait } \\
\text { dengan } \\
\text { penyeleng } \\
\text { garaan } \\
\text { perpustak } \\
\text { aan } \\
\text { masjid, } \\
\text { karena hal } \\
\text { ini baru } \\
\text { merupaka } \\
\text { n rintisan. }\end{array}$ & $\begin{array}{l}\text { Kegiatan } \\
\text { pemantauan } \\
\text { secara berkala } \\
\text { dilakukan oleh } \\
\text { tim penelitian } \\
\text { dan atau tim } \\
\text { PKM dari } \\
\text { perguruan } \\
\text { tinggi. } \\
\text { Perpustakaan } \\
\text { Masjid ini } \\
\text { nantinya akan } \\
\text { menjadi bagian } \\
\text { dari binaan } \\
\text { perguruan } \\
\text { tinggi } \\
\text { penggagasny } \\
\text { a dalam } \\
\text { melaksanaka } \\
\text { n tridarmanya. }\end{array}$ \\
\hline
\end{tabular}

\section{SIMPULAN}

1. Dalam konteks ibadah yang lebih luas dan bervariasi (ibadah ghoiru mahdoh), masjid dijadikan tempat atau pusat kegiatan yang 
tujuannya untuk kemaslahatan umat manusia. Salah satu kegiatan yang bisa dilakukan dengan kendali masjid adalah membina jamaah masjid untuk belajar menambah pengetahuan umum dan keagamaan berbasis membaca. Membaca itu suruhan Allah secara langsung kepada manusia seperti tercantum dalam Al-Qur'an Surat Al-'Alaq. Sarana dan fasilitas untuk kegiatan membaca di masjid dilakukan oleh Perpustakaan Masjid, yang tujuan jangka panjangnya adalah bisa mengikat jamaah untuk tetap menyenangi masjid dengan segala kegiatan keibadahannya.

2. Kebutuhan jamaah akan ilmu pengetahuan bisa dipenuhi dengan tersedianya sarana dan fasilitas bahan bacaan yang berkonten pengetahuan umum dan keagamaan. Adapun langkah-langkah metodisnya adalah dengan cara melakukan penelitian tindakan (action research) berbasis pendampingan kegiatan, yang meliputi: (1) Melakukan diskusi dan pembelajaran bersama dengan jamaah masjid mengenai membaca dan implikasinya bagi perkembangan intelektual umat islam pada umumnya; (2) Menyediakan sarana dan fasilitas berupa penyediaan koleksi buku dan media bacaan lain berkonten pengetahuan umum dan keagamaan; (3) Mendampingi jamaah belajar dan membaca sesuai dengan peminatan mereka.

3. Luaran yang diperoleh dengan semua langkah di atas adalah bahwa Perpustakaan Masjid bisa dijadikan sarana, fasilitas, dan media pembelajaran para jamaah masjid melalui kegiatan membaca bahan bacaan berkonten pengetahuan umum dan keagamaan. Para jamaah masjid menjadi termotivasi untuk menyempatkan diri membaca buku dan bahan bacaan lain yang disediakan oleh Perpustakaan Masjid.

\section{DAFTAR PUSTAKA}

Fjalbrant, Nancy dan Ian Malley. (1984). User Education in Libraries. Second Edition. London, Clive Bingley.

Katz, William A. (1978). Introduction to Reference Work, jilid ke-1: Basic Information Sources. New York, McGraw Hill.

Riding, Phil, Fowell, Sue and Levy, Phil. (1995) An action research approach to curriculum development. Information Research, 1 (1) Available at: http://InformationR.net/ir/11/paper2.html

Undang-undang Republik Indonesia No. 43 Tahun 2007. Undang-undang RI No. 43 Tentang Perpustakaan.

Waluyo, Subagio S. (2014). Peranan Perpustakaan Masjid Dalam Pembinaan Umat. Dewan Pengurus Cabang Partai Keadilan Sejahtera Jatiasih, Kota Bekasi.

Yusup, Pawit M. (2009). Ilmu Informasi, Komunikasi, dan Kepustakaan. Bumi Aksara, Jakarta.

Yusup, Pawit M. (2014). Membangun Komunitas Baca dan Usaha Bagi Anak-Anak Dari Keluarga Prasejahtera Di Desa Sukamukti Kecamatan Pamarican Kabupaten Ciamis. Laporan Akhir PENELITIAN IbM Dikti 2014. LPPM Unpad. 